INTERNATIONAL JOURNAL OF ENVIRONMENT

Volume-10, Issue-1, 2020/21

ISSN 2091-2854

Received: 26 February 2021

Revised: 31 May 2021

Accepted: 1 June 2021

\title{
DAILY CLIMATE EXTREMES OF TEMPERATURE AND PRECIPITATION OVER QUETTA VALLEY, PAKISTAN DURING 1961-2019
}

\author{
Imran Hameed Durrani ${ }^{1}$, Shahzada Adnan ${ }^{2}$ iD * , and Syed Mobasher Aftab ${ }^{1}$ \\ ${ }^{1}$ Faculty of Engineering and Architecture, Balochistan University of Information Technology, Engineering \\ and Management Sciences, Quetta, Pakistan \\ ${ }^{2}$ Pakistan Meteorological Department, Islamabad, Pakistan \\ *Corresponding author: shaz.adnan@gmail.com
}

\begin{abstract}
Climate extremes are imperative to study the impacts of climate change that is significantly observed for the management of scarce water resources of the Quetta Valley. The daily data of temperature and precipitation are used to model the climate extreme indices for Quetta Meteorological Station from1961 to 2019. The statistical tests were performed by using Mann Kendal and Sen's Slope method at the 95\% confidence level. The overall change in minimum to maximum temperatures and precipitation-based climate extreme indices specify the frequencies of extreme events are increasing. That would cause heatwaves, gradual warming, steady dryness, and extreme precipitation events in the long term over the Quetta Valley. The minimum and maximum temperature-based indices inclusively indicate positive trends. That ultimately leads to a warming climate with a significant increase in summer as 5 days/decade, tropical nights as 5.3 days/decade, daily maximum as $0.28^{\circ} \mathrm{C} /$ decade, warm nights as 1.7 days/decade and warm days as 1.9 days/decade. For precipitation, all the indices show positive trends with a significant increase in consecutive wet days for 0.1 days/decade and an annual contribution of very wet days $0.8 \%$ per decade. The monthly increase in temperature and decrease in precipitation would increase the evaporative demands which may arise the water stress conditions over the valley and may put pressure over groundwater reservoirs.

Keywords: Climate Extremes; Climatic Indices; Quetta Valley; Pakistan.
\end{abstract}

DOI: http://dx.doi.org/10.3126/ije.v10i1.38401

Copyright @2021 IJE

This work is licensed under a CC BY-NC which permits use, distribution and reproduction in any medium provided the original work is properly cited and is not for commercial purposes 


\section{Introduction}

The impacts of climate extremes are observed and gain attention throughout the world (Alexander $e t$ al., 2006). It was projected that average global temperature would increase 1.4 to $5.8^{\circ} \mathrm{C}$ during the $21^{\text {st }}$ century and the frequency of extremes events, i.e., floods, droughts, and heatwave would also be increased (IPCC, 2007). Several researchers conducted work over the world regarding the changes in extreme temperature and precipitation based on observation data sets (Frich et al., 2002; Meehl et al., 2004; Griffith et al., 2005; and Tebaldi et al., 2006). The future projected study also shows the frequency of climate extreme increases over Pakistan (Sajjad and Ghaffar, 2018). These studies identified the changes in climate extreme of precipitation and temperature and its related indices over the Quetta valley of Pakistan.

The world consensus shows that the environment is highly sensitive to shifts in frequency and intensity of extreme events (Boccolari \& Malmusi, 2013). The indices based on percentile, threshold, duration and other statistical tools may be utilized to represent extreme events (Grigges and Noguer, 2002). The Expert Team on Climate Change Detection and Indices (ETCCDI) has proposed a set of climate indices that are used globally to investigate the extremes in observed data as well as for future projections of climatic extremes over a region (Zhang et al., 2011). Numerous researchers (Frich et al., 2002; Klein Tank et al., 2003; Meehl et al., 2004 and Tebaldi et al., 2006 etc.) concentrated on data collection from ground weather stations to study the climate extreme indices.

In many countries around the world, hot days and warm nights have been increased, whereas cold days and cold nights have been decreased and precipitation significance varies from region to region (Manton et al., 2001). The gradual reduction in cold days and increase in warm days is identified since 1961 over China (Yan et al., 2002). Similarly, trends of precipitation extreme indices have increased during 1910-2000 in 70\% of the studies conducted in most areas of the world (Sen Roy and Balling, 2004). The change (direction and magnitude) in extreme climate does not necessarily remain the same to climate means (IPCC, 2007). Earlier studies conducted on the mean climate and climate extremes over south Asia (Choi et al., 2009; Ahmad et al., 2015; Sajjad and Ghaffar, 2018).

Climate change invariably affects the global hydrological cycle as well as air temperature (Hunt, 2020; Zhao, 2015). The global land surface temperature has risen at the rate of $0.175^{\circ} \mathrm{C}$ to $0.197^{\circ} \mathrm{C}$ per decade during 1951-2012 (Stocker et al., 2013). Extreme weather events have increased worldwide in terms of 
frequency and intensity (Huber and Gulledge, 2011). Several studies suggest that climate change may widen the production and consumption gap between the nations as the agriculture productivity in developed countries will increase while it will decrease in developing countries (Rosenzweig and Parry, 1994; Fischer et al., 2005). It is expected that millions of more people will face hunger by 2050 (Parry et al., 2004).

A previous study on extreme temperature identified that it falls to $-26^{\circ} \mathrm{C}$ in the northern area and reaches $52^{\circ} \mathrm{C}$ in the central as well as southern parts of Pakistan (Srinivas and Kumar, 2006). Also, the air temperature has shown a rising trend of $0.06^{\circ} \mathrm{C}$ per decade from 1901 to 2007 (Afzaal et al., 2009). To investigate the climate variations and trends over Pakistan, many studies have been conducted in recent years (e.g., Treydte et al., 2006; Del Rio et al., 2012; Hanif et al., 2013). Mean annual temperature has increased at $0.36^{\circ} \mathrm{C} /$ decade in Pakistan during 1952-2009 (Del Rio et al., 2012). The annual precipitation has gradually increased over southwestern parts and the Cholistan desert of the country during 1951-2010 (Hussain and Lee, 2014). The studies of Kazmi et al. (2015) and Ikram et al. (2016) indicated that the past trends of increasing temperature in Pakistan may continue during the current century. The southern parts of Pakistan are arid and most vulnerable to drought as indicated by Haider and Adnan (2014). Also, the frequency and intensity of drought in the southern parts of Pakistan are high, especially in the Sindh province (Adnan et al., 2015).

Diagnosis of extreme events in terms of intensity, duration and frequency is crucial to frame mitigation and adaptation strategies to counter the impacts due to climate change (Choi et al., 2009). Previously, several studies were conducted based on mean climate over different South Asian domains (Ahmad et al., 2015; 2018 etc.). However, the present study is conducted only for Quetta Valley by using observational data of precipitation and temperature to identify the climate extreme indices and their trends. The main objective of the study is to identify the climate extremes events that may create disaster regarding heat/cold wave, droughts, flood, and, most importantly, the agricultural water demands over the region. The findings of this study will help the water resource managers, climate research scientists, agriculturist, agronomists and disaster risk management agencies to develop a contingency plan for sustainable environment and climate-smart agriculture to cope with the future challenge of climate change and its extremes. 


\section{Study area}

Most parts of the Balochistan province including Quetta lie in an arid climate with significant variation between summer and winter temperature (Adnan and Ullah, 2020). The Quetta Valley lies at 30.18 latitudes and 66.99 longitudes with an elevation of $1680 \mathrm{~m}$. The Quetta Valley is one among nine sub-basins of the Pishin river basin with a total watershed area of $1757 \mathrm{~km}^{2}$; the geographical location is shown in Figure1.

The only source for recharging the groundwater of the Quetta valley is precipitation. The mean annual rainfall in the valley is about $210 \mathrm{~mm}$, over $80 \%$ of which falls during the winter months from November to April. The rise in water levels was also observed from January to mid of April, and this recharge is due to the seasonal precipitation (Gazdar et al., 2010). Western depressions bring precipitation over this region during winter, the temperature drops down to freezing level (Durrani et al., 2018). At the valley, the monthly mean minimum temperature ranges from -2.73 to $20.51^{\circ} \mathrm{C}$ with the lowest in January and highest in July respectively. Similarly, the monthly mean maximum temperature varies from $11.06^{\circ} \mathrm{C}$ to $36.28{ }^{\circ} \mathrm{C}$ during January (lowest) and July (highest). Furthermore, the mean precipitation range varies from 2.29 to $51.52 \mathrm{~mm}$ with the lowest in June and highest in January respectively.

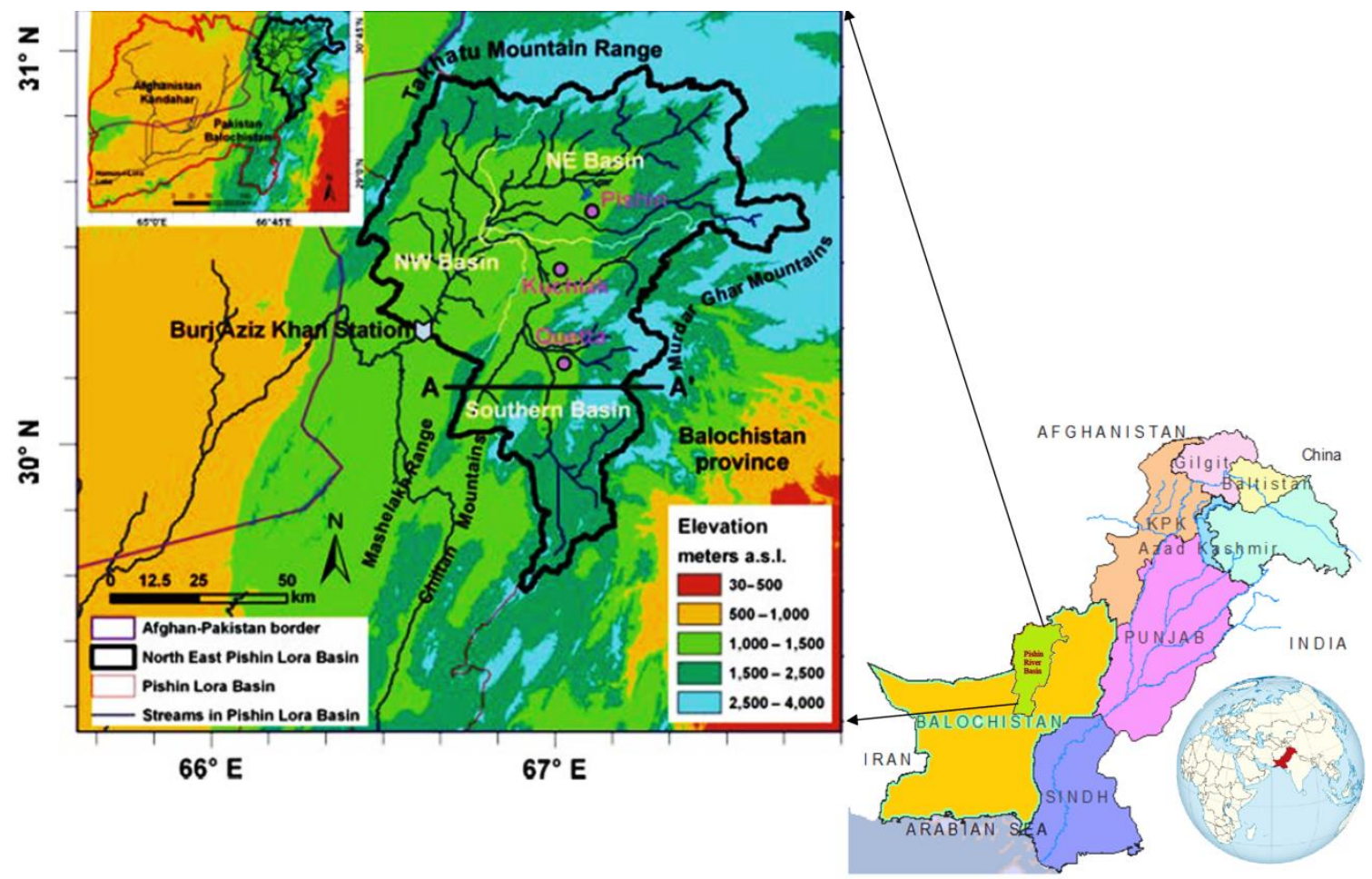

Figure 1: Geographical location of Quetta Valley, Sub-basin of Pishin River Basin (Source Sagintayev et al., 2012). 
At the present concept of water availability from karezes, and dug wells are almost eliminated few dug wells are still being used in the west of Quetta valley and about $95 \%$ of water availability is dependent on water supplied through tubewells from alluvium and hard rock aquifers the remaining $5 \%$ is through springs active in Urak and $3126 \mathrm{~m} /$ day is collected in the reservoirs and $2748 \mathrm{~m}^{3} /$ day is being supplied to the Cant area while $378 \mathrm{~m}^{3}$ is supplied as support to the city water supply. According to the Quetta action plan, 2010, the water points in Quetta sub-basin are shown in Table A1 (see Appendix).

According to Ashraf and Hassan, (2020) report revealed that the assessed availability of sustainable groundwater in alluvium and hard rock aquifers from the year 2000 to 2042 as shown in Table A2 (see Appendix). To avoid water mining, the supplementary water requirements were recommended to be arranged from surface water availability in and around the Quetta valley. The groundwater in Quetta Valley generally occurs under water table conditions, but artesian conditions do exist in some parts of the valley.

The district of Quetta has two cropping seasons: 1. Rabi Crops: Rabi crops include wheat, barley, cumin, vegetables and fodder. These crops are sown in winter or during the early summer and harvested in the late summer. 2. Kharif Crops: melons, fruits, vegetables, potato, fodder and onion come under cash crops; they are sown in the summer and harvested in the late summer or early winter.

Fruit production is very important and dominant in district Quetta as $48.7 \%$ of the irrigated area was under fruit production. Apple, apricot, grapes, peach, plum, pear and cherry are the leading fruits of district Quetta. Among the cereal crops grown in the Quetta district, wheat and barley are the leading cereal crops. The average yield of 2,060 kg/ha was recorded in wheat followed by barley having $1,510 \mathrm{~kg} / \mathrm{ha}$ yield during the year 2017-18. Data from the list of major crops revealed that the contribution of fruits for the year 201718 remained topmost covering $48.7 \%$ area followed by wheat with $28.6 \%$ area. Vegetables stood $3^{\text {rd }}$, thereby occupying $6.1 \%$ of the total area under major crops. However, the lowest area of only $0.6 \%$ was recorded in potatoes, followed by melons having $0.9 \%$ contribution in the cultivable soils of district Quetta.

\section{Methodology}

\subsection{Climate Indices}

The daily observational data of rainfall and minimum and maximum temperature for the Quetta station was used. The core 27 climate indices were used to monitor the trends during 1961-2019 by adopting the criteria to select the parameters whose missing values are less than $20 \%$ of the daily values as suggested 
by Manton et al., 2001. These 27 climate extreme indices are recommended by the Expert Team on Climate Change Detection and Monitoring Indices (ETCCDMI), the World Meteorological Organization, Table A3 (see Appendix). Out of 27 climate extreme indices, 16 are related to temperature and 11 to precipitation (Alexander et al., 2006) and also present at the CLIMDEX project website http://www.climdex.org. The remaining four indices mean maximum and minimum temperature is directly calculated whereas two indices, i.e., extreme temperature range (ETR) and an annual contribution of very wet days (R95PT)) are calculated by using the equation mentioned in Table 1 . Indices are related to 9 warm and 7 cold temperatures, the categorization based on methods of calculations. Accordingly, these indices are categorized in 4 percentile, 4 thresholds, 5 absolute, 3 duration indices and 3 others. The precipitation indices comprised of 11 wet and 1 dry index that is categorized into 2 percentiles, 3 thresholds, 2 absolute, 2 durations, and 3 others.

Based on the relative threshold for the temperature indices, the $10^{\text {th }}$ percentile of the 53-year average of daily temperature at Quetta Meteorological Station is calculated for each of the 365 days of the year. These percentile-based indices include lower and higher extremes for cool and warm days along with nights respectively. The cold spell duration index (CSDI) and warm spell duration index (WSDI) are also calculated based on the percentile values of cool and warm days. The monthly extreme temperature indices, i.e., the lowest and highest daily minimum and maximum temperatures TXx, TXn, TNx and TNn, and diumal temperature range (DTR) based on percentiles. The indices using the fixed thresholds includes frost days (FD0), summer days (SU25), ice days (ID0), tropical nights (TR20) and growing season length (GSL).

The relative threshold for precipitation-based indices on first (R99p) and upper fifth (R95p) percentile values is used to calculate the extreme or very wet day precipitation. Single-day total precipitation (RX1day) is used to determine the monthly maximum five-day precipitation (RX5day) for consecutive days at Quetta. The consecutive dry days (CDD) and consecutive wet days (CWD) are used to determine the characteristic of extreme precipitation. Whereas; the annual average precipitation is represented by annual total wet days precipitation (PRCPTOT) and trends in simple daily intensity index (SDII). Extreme precipitation events are also calculated for a threshold of $10 \mathrm{~mm}(\mathrm{R} 10)$ and $20 \mathrm{~mm}$ (R20). Additionally, extreme temperature range and an annual contribution of very wet days are also considered.

\subsection{Data Homogenizing}

R-ClimDex (1.0) climate model is used for calculating indices of climate extreme for Quetta Valley and 3 (sigma) standard deviation levels was used to identify the outlier data. The selected station's data was 
formatted for further quality check and control with R-ClimDex and linear regression for trend calculations. The model is developed by Xuebin and Yang (2004) at the climate research branch of the meteorological service of Canada. The R-ClimDex computed threshold indices for 52 years from 1961-2019. The temperature thresholds include summer days, tropical nights, frost days and icy days. The precipitation indices use thresholds for heavy rainfall events, seasonal trends, extremes etc.

The homogeneity and quality control of all the outliers was checked like the repeated values, sudden jumps in the series and maximum temperature less than the minimum temperature. The obvious data was sorted out and replaced by -99.9 . The major gaps were removed and rectified by the available documented data of the Pakistan Meteorological Department for Quetta Station. Gap filling was performed by using criteria of a fixed number of days with missing data. If the number of consecutive days with missing data was less than or equal to five, the gap-filling was done by using interpolation among these values and keeping in view not to miss a heatwave, a cold wave, or an extreme precipitation event. For missing data greater than five, the whole month was excluded from the analysis so that it may not render a false contribution in the trend analysis.

Several checks were considered while performing the quality control for the data. The outliers were identified and set to missing values for maximum and minimum temperature, using $3 \times$ standard deviation criteria. For precipitation, corresponding daily values of monthly maxima were searched in the monthly climatic normal of Pakistan and set as upper limit thresholds for the identification of precipitation outliers. Quality checks were performed for values showing minimum temperature $\geq$ maximum temperature. To calculate $\mathrm{R}_{\mathrm{nn}}$ index, the threshold of $23 \mathrm{~mm}$ for the region was utilized. Two thresholds were taken to consider for Ice days index (ID0) i.e. $0^{\circ} \mathrm{C}$ and $11^{\circ} \mathrm{C}$. Two new indices namely extreme temperature range (ETR) and an annual contribution of very wet days (R95PT) were identified.

\subsection{Mann-Kendall and Sen's Estimator}

The temporal trends and magnitude of trends for each of the indices are determined by using Mann Kendall and Sen's Slope (non-parametric) methods at 95\% confidence level (Mann 1945, Sen 1968). The linear trend of monthly, seasonal and annual precipitation and temperature are calculated using Mann Kendal Test, which has been broadly used to analyze the long term climatological and hydrological time series (Zhang et al., 2010; Tabari et al., 2011; Tabari et al., 2012; Du et al., 2013; Gocic and Trajkovic, 2014, Zhang et al., 2015, Adnan et al., 2016,17,18). The following equation is used to calculate the variance of the equation: 


$$
\operatorname{Var}(S)=\frac{1}{18}\left[n(n-1)(2 n+5)-\sum_{p=1}^{q} t_{p}\left(t_{p}-1\right)\left(2 t_{p}+5\right)\right]
$$

Where $q$ number has the same value of sample data and $t_{p}$ is the data values of the $\mathrm{p}^{\text {th }}$ group.

The statics $\mathrm{S}$ is:

$$
S=\sum_{j=1}^{n-1} \sum_{k=j+1}^{n} \operatorname{sgn}\left(x_{k}-x_{j}\right)
$$

Where $\mathrm{j}$ and $\mathrm{k}$ are the data values, $\mathrm{n}$ represents the data length and $\operatorname{sgn}(\theta)$ is a significant function that varies from -1 to 1 .

$$
\mathrm{Z}=\left\{\begin{array}{cc}
\frac{S-1}{\sqrt{\operatorname{Var}(S)}} & \text { if } S>0 \\
0 & \text { if } S=0 \\
\frac{S+1}{\sqrt{\operatorname{Var}(S)}} & \text { if } S<0
\end{array}\right.
$$

The value of $\mathrm{Z}$ is approximately normal distributed and the positive value of $\mathrm{Z}$ greater than 1.96 represents the significant increasing trend, whereas a negative value lower than -1.96 donates a significant decreasing trend.

The true slope (change per unit time) of linear time series trend is determined by Sen (1968).

$$
f(t)=M t+C
$$

Where $\mathrm{f}(\mathrm{t})$ is the function of a linear trend, $\mathrm{M}$ and $\mathrm{C}$ are the slopes and constant of the equation respectively.

This method estimates the magnitude of trend as follows:

$$
\mathrm{Q}=\operatorname{median} \frac{\mathrm{x}_{\mathrm{i}}-\mathrm{x}_{\mathrm{j}}}{\mathrm{t}_{\mathrm{i}}-\mathrm{t}_{\mathrm{j}}}
$$

Where $x_{i}$ and $x_{j}$ are the data values at times $t_{i}$ and $t_{j}(i>j)$, respectively.

The trend and magnitude of the trend were calculated for Quetta valley using Mann Kendal and Sen's Slope method at the 95\% significance level during 1961-2019 Table-3. The values of man Kendal on onetailed test are \pm 1.645 to identify the trend significance at the $95 \%$ level as described by Adnan et al., 2017 . The significant values are highlighted in bold representing the Mann Kendal, whereas the values are representing the magnitude of the trend (change per decade) using Sen's slope. 


\section{Results and discussion}

\subsection{Climate Extreme Indices Analysis}

The statistical significance of climate-based indices analyzed by Mann Kendal and Sen's Slope method for Quetta valley are presented in Table 4. The results of the indices analysis represent those frost days decreased significantly by -6.38 days/decade when the minimum temperature fell below $0^{\circ} \mathrm{C}$ over the Quetta valley (Table 2). A significant increase in summer days by 5.0days/decade and tropical nights by 5.27days/decade was observed when the daily maximum temperature exceeds $25^{\circ} \mathrm{C}$ and $20^{\circ} \mathrm{C}$ respectively. The monthly maximum value of daily maximum temperature has increased significantly at $0.28^{\circ} \mathrm{C} / \mathrm{decade}$. The percentage of cool nights and days has significantly decreased by -3.75 days/decade and -1.34 days/decade at the tenth percentile. Whereas, warm nights and warm days have significantly increased by 1.70 days/decade and 1.92 days/decade at the $90^{\text {th }}$ percentile respectively. These results show significant warming trends over Quetta valley. The cold spell duration has been decreased significantly by -1.12 days/decade when the minimum temperature is less than the tenth percentile for consecutive six days. The diurnal temperature range has decreased significantly by -0.25 days/decade, represents the difference between the maximum and minimum temperatures have become lessen. The consecutive wet days have increased by 0.10 days/decade, which represents rainy days have increased significantly. The significant increase in mean maximum $0.61^{\circ} \mathrm{C} /$ decade and mean minimum temperature by $0.37^{\circ} \mathrm{C} /$ decade is a positive indication of temperature rise and warming trends over Quetta Valley. The extreme temperature range of $0.28^{\circ} \mathrm{C} /$ decade and annual total precipitation of wet days by $13.8 \mathrm{~mm} /$ decade has increased, but it is insignificant. However, the annual contribution of very wet days has increased by $0.80 \% /$ decade significantly.

The results indicate a significant increase in minimum and maximum temperature-based indices. That shows a warming trend, whereas the precipitation base indices represent an increase, but it is statistically insignificant at the $95 \%$ confidence level. The increase in temperature-based indices may put pressure on to trigger evapotranspiration, soil moisture, groundwater and, most importantly, the excessive crop water demand for the Quetta valley (Durrani et al., 2018). 
Table 4: Statistical significance of climate-based indices analyzed by Mann Kendal and Sen's Slope method for Quetta valley.

\begin{tabular}{|c|c|c|c|c|c|}
\hline Category & $\begin{array}{l}\text { Index name } \\
\text { Temperature }\end{array}$ & Sen'Slope & Category & $\begin{array}{l}\text { Index name } \\
\text { Precipitation }\end{array}$ & Sen'Slope \\
\hline \multirow{4}{*}{ Percentile } & TN10p & -3.75 & \multirow{3}{*}{ Percentile } & R95p & 3.74 \\
\hline & TX10p & -1.34 & & R99p & 2.52 \\
\hline & TN90p & 1.70 & & $\mathrm{R} 10$ & 0.00 \\
\hline & TX90p & 1.92 & \multirow[t]{2}{*}{ Threshold } & $\mathrm{R} 20$ & 0.29 \\
\hline \multirow{4}{*}{ Threshold } & FD0 & -6.38 & & Rnn & 0.00 \\
\hline & SU25 & 5.00 & \multirow{2}{*}{ Absolute } & RX1day & 1.75 \\
\hline & $\mathrm{ID} 0$ & -0.09 & & RX5day & 2.29 \\
\hline & TR20 & 5.27 & \multirow{2}{*}{ Duration } & CDD & 4.29 \\
\hline \multirow{5}{*}{ Absolute } & TXx & 0.28 & & CWD & 0.10 \\
\hline & TNx & 0.13 & \multirow{2}{*}{ Other } & PRCPTOT & 13.80 \\
\hline & TXn & 0.01 & & SDII & 0.02 \\
\hline & $\mathrm{TNn}$ & 0.18 & \multicolumn{2}{|c|}{ TMAXmean } & 0.61 \\
\hline & DTR & -0.25 & \multicolumn{2}{|c|}{ TMINmean } & 0.37 \\
\hline \multirow{3}{*}{ Duration } & GSL & 3.43 & \multicolumn{2}{|c|}{ R95PT } & 0.80 \\
\hline & WSDI & 1.48 & & & \\
\hline & CSDI & -1.12 & & & \\
\hline ETR & & 0.28 & & & \\
\hline
\end{tabular}

*Bold values represent statistical significance at $95 \%$ confidence level using Mann Kendal test.

The monthly temperature (maximum, minimum) and precipitation data (1961-2019) of Quetta valley is used to identify the trends at the $95 \%$ significance level (Table 5). The highest significant change in mean monthly minimum temperature $\left(0.10^{\circ} \mathrm{C} /\right.$ year $)$ was observed during May and October, whereas the mean monthly maximum temperature change was highest $\left(0.05^{\circ} \mathrm{C} /\right.$ year $)$ during April at the $95 \%$ confidence level. However, no significant change in precipitation was observed over the valley. The study provides scientific evidence of climate extreme events that may help the climate change managers and policymakers to develop the contingency plan towards the sustainable surface and groundwater development for Quetta valley. 
Table 5: Monthly mean minimum and maximum temperature and precipitation at Quetta Valley along with change per year from 1961-2019.

\begin{tabular}{|c|c|c|c|c|c|c|}
\hline \multirow{3}{*}{ Months } & \multicolumn{4}{|c|}{ Temperature $\left({ }^{\circ} \mathrm{C}\right)$} & \multirow{2}{*}{\multicolumn{2}{|c|}{$\begin{array}{l}\text { Precipitation } \\
\quad(\mathbf{m m})\end{array}$}} \\
\hline & \multicolumn{2}{|c|}{ Minimum } & \multicolumn{2}{|c|}{ Maximum } & & \\
\hline & Mean & $\begin{array}{l}\text { Change } \\
\text { per year }\end{array}$ & Mean & $\begin{array}{l}\text { Change } \\
\text { per year }\end{array}$ & Mean & $\begin{array}{l}\text { Change } \\
\text { per year }\end{array}$ \\
\hline January & -2.73 & 0.05 & 11.06 & 0.04 & 51.52 & -0.29 \\
\hline February & -0.46 & 0.03 & 13.37 & 0.01 & 51.11 & 0.49 \\
\hline March & 4.04 & 0.05 & 19.13 & 0.04 & 48.21 & -0.10 \\
\hline April & 8.87 & 0.05 & 25.30 & 0.05 & 28.32 & -0.10 \\
\hline May & 12.73 & 0.10 & 30.92 & 0.05 & 6.34 & 0.00 \\
\hline June & 17.05 & 0.10 & 35.34 & 0.01 & 2.29 & 0.00 \\
\hline July & 20.51 & 0.06 & 36.28 & 0.03 & 11.99 & -0.00 \\
\hline August & 18.57 & 0.06 & 35.13 & 0.02 & 9.23 & 0.00 \\
\hline September & 11.89 & 0.09 & 31.62 & 0.03 & 2.55 & 0.00 \\
\hline October & 5.01 & 0.10 & 25.59 & 0.02 & 4.51 & 0.00 \\
\hline November & 0.23 & 0.10 & 19.54 & 0.04 & 7.01 & 0.00 \\
\hline December & -2.41 & 0.06 & 14.19 & 0.05 & 30.48 & -0.11 \\
\hline Annual & 7.77 & 0.07 & 24.79 & 0.03 & 253.57 & 0.97 \\
\hline
\end{tabular}

Note: Bold value represents the magnitude of the trend at $95 \%$ significance level

\subsection{Trends in Temperature Indices}

The frequency distribution analysis for temperature indices over Quetta valley during the two different periods, i.e., 1961-1990 and 1991-2019, were conducted. The analysis was based on daily maximum temperature, daily minimum temperature, and both because the temporal variations of the daytime temperature can be different from those of the nighttime temperature (Vincent et al. 2005). The maximum change between the two means was observed on warm spell duration(WSDI) and cold spell duration (CSDI) as it has increased by $174.56 \%$ and decreased by $-83.20 \%$ over Quetta at the $95 \%$ significance level respectively. A Similar increase change has been observed for TX90P, TN90P, TR20, TMINmean, SU25, TMAXmean and TXx, whereas it has decreased for TN10P, TX10P, FD2 and FD0 at the 95\% significance level. The temperature increase has significantly increased the warm days and night along with the extreme maximum temperature and summer days over the valley (Folland et al., 2002). Moreover, cool days, frost days have also decreased significantly. These results indicate the warming trend that may enhance the crop water requirement and evapotranspiration rate over Quetta. The same results have been obtained for major cities of Punjab province as determined by Abbas, 2013. The majority of the temperature indices have 
increased (TXn, GSL, ETR and TNx) except (DTR, TNn, ID0) during 1991-2019 in comparison to 19611985, but they are not statistically significant at the $95 \%$ level.

The time series characterize for the indices of summer days (SU25), ice days (ID0), monthly maximum of daily maximum temperature (TXx), the monthly minimum value of daily maximum temp (TXn), cool days (TX10P), warm days (TX90P), warm spell duration indicator (WSDI), and the mean monthly maximum temperature (TMAXmean). The said time-series indices are shown in Figure 2, the black solid line represents the trend of an individual index at Quetta valley. Time series demonstrate an overall increasing trend between extreme climatic indices for SU25, TXx, TX90P, WSDI, and TMAXmean. Similarly, the time series graphs represent a declining trend for the individual index of IDO and TX10P, while a consistent trend is observed for the TXn. These trends show more heatwaves are expected in the future over Quetta. The frequency distribution analysis for temperature indices over Quetta Valley from 1961-1990 and 1991-2019 are as shown in Table 6.

Table 6: Frequency distribution analysis for 20 temperature indices for two periods: 1961-1990 and 19912019 for Quetta Valley.

\begin{tabular}{|c|c|c|c|c|c|}
\hline \multirow[b]{2}{*}{ Category } & \multirow[b]{2}{*}{ Index } & \multicolumn{2}{|c|}{ Mean } & \multirow{2}{*}{$\begin{array}{c}\text { Change } \\
\text { between two } \\
\text { means }\end{array}$} & \multirow{2}{*}{$\begin{array}{c}\mathbf{P} \\
\text { Value }\end{array}$} \\
\hline & & (1961-1990) & (1991-2019) & & \\
\hline \multirow{4}{*}{ Percentile } & TN10p & 18.99 & 6.49 & -65.82 & 0.00 \\
\hline & TX10p & 13.3 & 8.41 & -36.77 & 0.00 \\
\hline & TN90p & 6.45 & 11.81 & 83.00 & 0.00 \\
\hline & TX90p & 5.78 & 11.68 & 102.27 & 0.00 \\
\hline \multirow{4}{*}{ Threshold } & FD0 & 81.67 & 68.52 & -16.10 & 0.02 \\
\hline & SU25 & 180.95 & 192.43 & 6.34 & 0.01 \\
\hline & ID0 & 0.73 & 0.61 & -16.30 & 0.34 \\
\hline & TR20 & 31.9 & 46.26 & 45.00 & 0.00 \\
\hline \multirow{5}{*}{ Absolute } & $\mathrm{TXx}$ & 39.28 & 40.1 & 2.09 & 0.00 \\
\hline & $\mathrm{TNx}$ & 24.29 & 24.72 & 1.76 & 0.14 \\
\hline & TXn & 1.72 & 1.84 & 6.89 & 0.35 \\
\hline & $\mathrm{TNn}$ & -10.3 & -9.85 & -4.37 & 0.18 \\
\hline & DTR & 16.87 & 16.43 & -2.64 & 0.15 \\
\hline \multirow{3}{*}{ Duration } & GSL & 322.48 & 332.91 & 3.24 & 0.06 \\
\hline & WSDI & 2.45 & 6.74 & 174.56 & 0.02 \\
\hline & CSDI & 21.48 & 3.61 & -83.20 & 0.00 \\
\hline \multirow{2}{*}{ Others } & TMINmean & 7.29 & 8.8 & 20.71 & 0.00 \\
\hline & TMAXmean & 24.23 & 25.26 & 4.27 & 0.00 \\
\hline ETR & & 37.56 & 38.27 & 1.87 & 0.31 \\
\hline
\end{tabular}


A significant change between the two means of all percentile indices has been observed at the $95 \%$ confidence level. Similarly, all indices of threshold values except ice days have also been changed significantly. Moreover, the warmest days, wet spells and cold spells duration and mean of maximum and minimum temperature has significantly changed for a period of 1961-1990 and 1991-2019. The time-series data analyzed for extreme changes in temperatures in 1961-2019 at Quetta valley. The minimum temperaturebased indices are presented in Figure 2. The trends of frost days, cool days and cool spell duration are sharply decreasing, whereas the mean minimum temperature, tropical nights, warm nights and an annual minimum of daily maximum, as well as annual minimum of the daily minimum, are increasing, which represents the warming trends over Quetta valley. Rare climate trends show an overall decrease (increase) in the number of cool nights and cool days (hot nights and hot days) may be due to real but local urban heat island effects (You et al., 2008). 

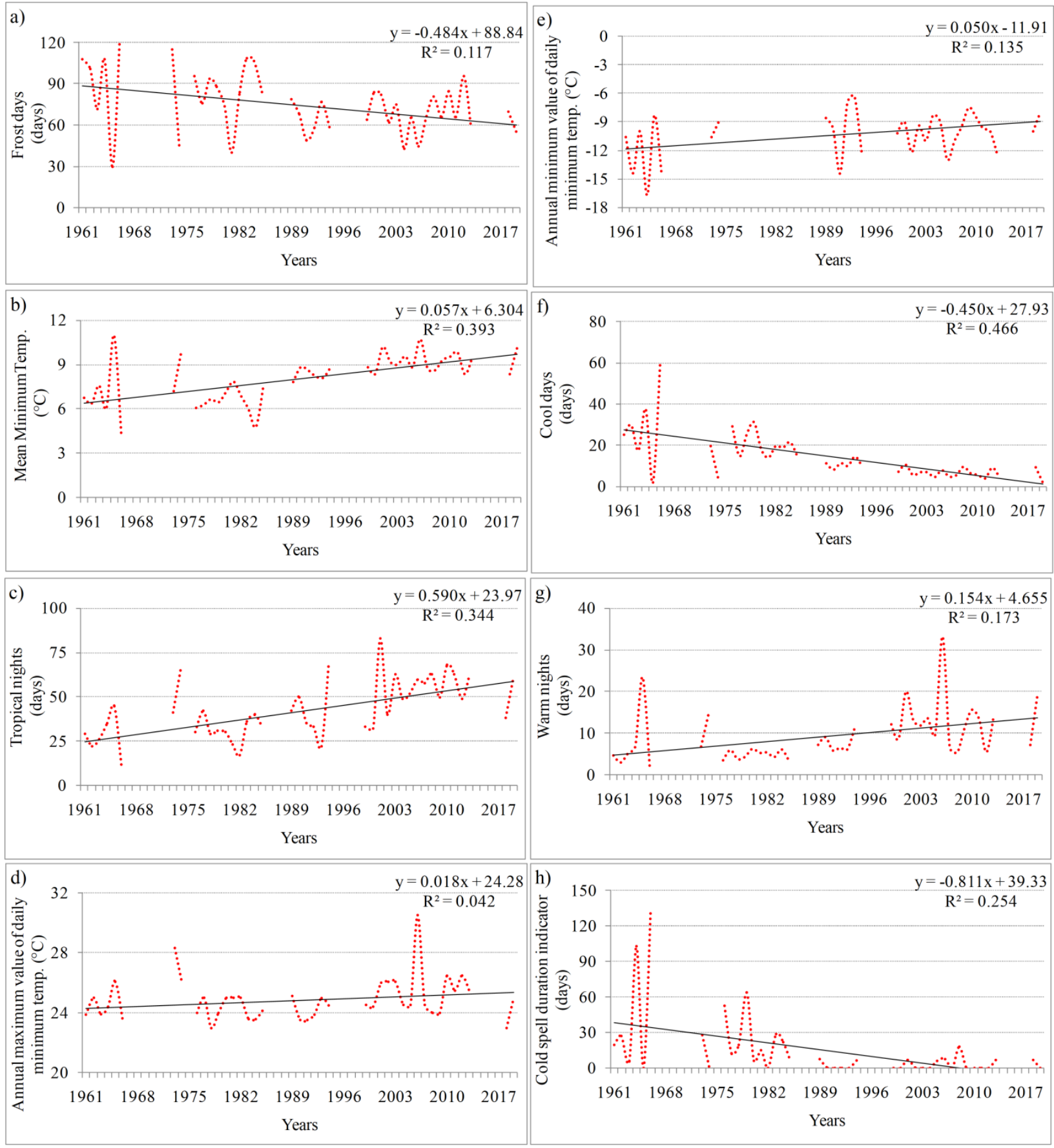

Figure 2 (a-h): Climate extremes indices based on the daily minimum temperature of Quetta Valley. 

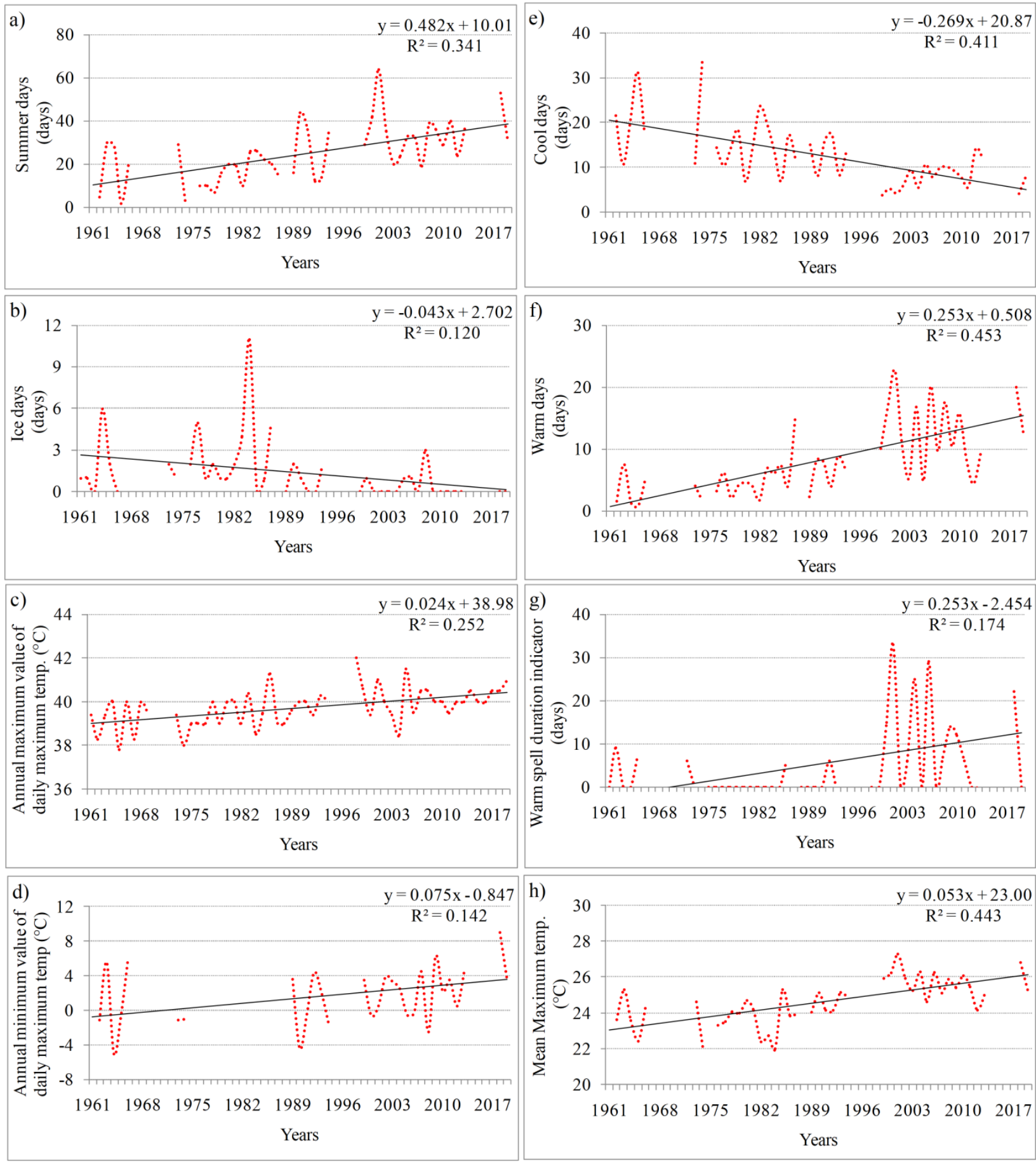

Figure 3 (a-h): Climate extremes indices based on the daily maximum temperature of Quetta Valley.

The temperature threshold for ice days and cool days is decreasing, whereas the summer days are increasing. Similarly, the ice days are decreasing, whereas the summer days, warm days, warm spell duration, mean maximum temperature, as well as an annual maximum of daily maximum and an annual minimum of daily maximum, are increasing. These results show a clear indication of warming over the days and nights as shown in Figure 3. The absolute temperature for warmest days to warmest nights and coldest day to coldest nights along with the diumal temperature range is shown in Figure 2. These results indicate a positive increase 
for warmest days to warmest nights and coldest days to coldest nights. The annual value of the daily maximum and minimum temperature are increasing, showing an increase in the warmest days and nights along with coldest days and nights over the Quetta valley. The negative trend in the diurnal temperature range indicates that the temperature range between maximum and minimum temperature is decreasing. The results depict that the diurnal temperature range lies between 11.0 to $20.5^{\circ} \mathrm{C}$ with a maximum $\left(20.5^{\circ} \mathrm{C}\right.$ and $\left.45^{\circ} \mathrm{C}\right)$ during 1966. Urbanization and land-use change play a significant role in surface warming at the local scale (Kalnay and Cai 2003; Safeeq et al., 2013), though these human-induced changes do not bias surface warming at a global scale. The significant impact of human-induced land-use changes has been reported on Tibetan Plateau through a modelling approach (Li and Xue, 2010). The impacts of increased irrigation have been determined on long-term temperature trends (Roy et al., 2007). An increase of maximum temperature to higher limits (i.e., $40^{\circ}-50^{\circ} \mathrm{C}$ ) can adversely affect wheat, cotton, or vegetable yield because a failure of only one critical enzyme system, in above temperature limits, can cause the death of an organism (Abrol and Ingram, 1996).

\subsection{Trends in Precipitation Indices}

The daily precipitation data (1961-2019) has been used to calculate the climate extreme indices of Quetta valley as shown in Figure 4. Time series for the indices of Max 1-day precipitation amount (RX1day), Max 5-day precipitation amount (RX5day), Simple daily intensity index (SDII), Number of heavy precipitation days (R10mm), Number of very heavy precipitation days (R20mm), Consecutive dry days (CDD), Number of days above (nn mm Rnn), Very wet days (R95p), Extremely wet days (R99p), Annual total wet-day precipitation (PRCPTOTAL), and Consecutive wet days (CWD). The increasing or decreasing trends are shown with a black solid line.

The precipitation over Quetta valley shows a slightly increasing trend for the entire precipitationrelated variable. The precipitation percentile for very wet to extremely wet days has shown a positive increasing trend as shown in Figure 4. The precipitation threshold for an annual count of days for precipitation greater than equal to 10,20 and 23mm was calculated as shown in Figure 4. All the three variables show a positive increasing trend with the highest in 1982. The 

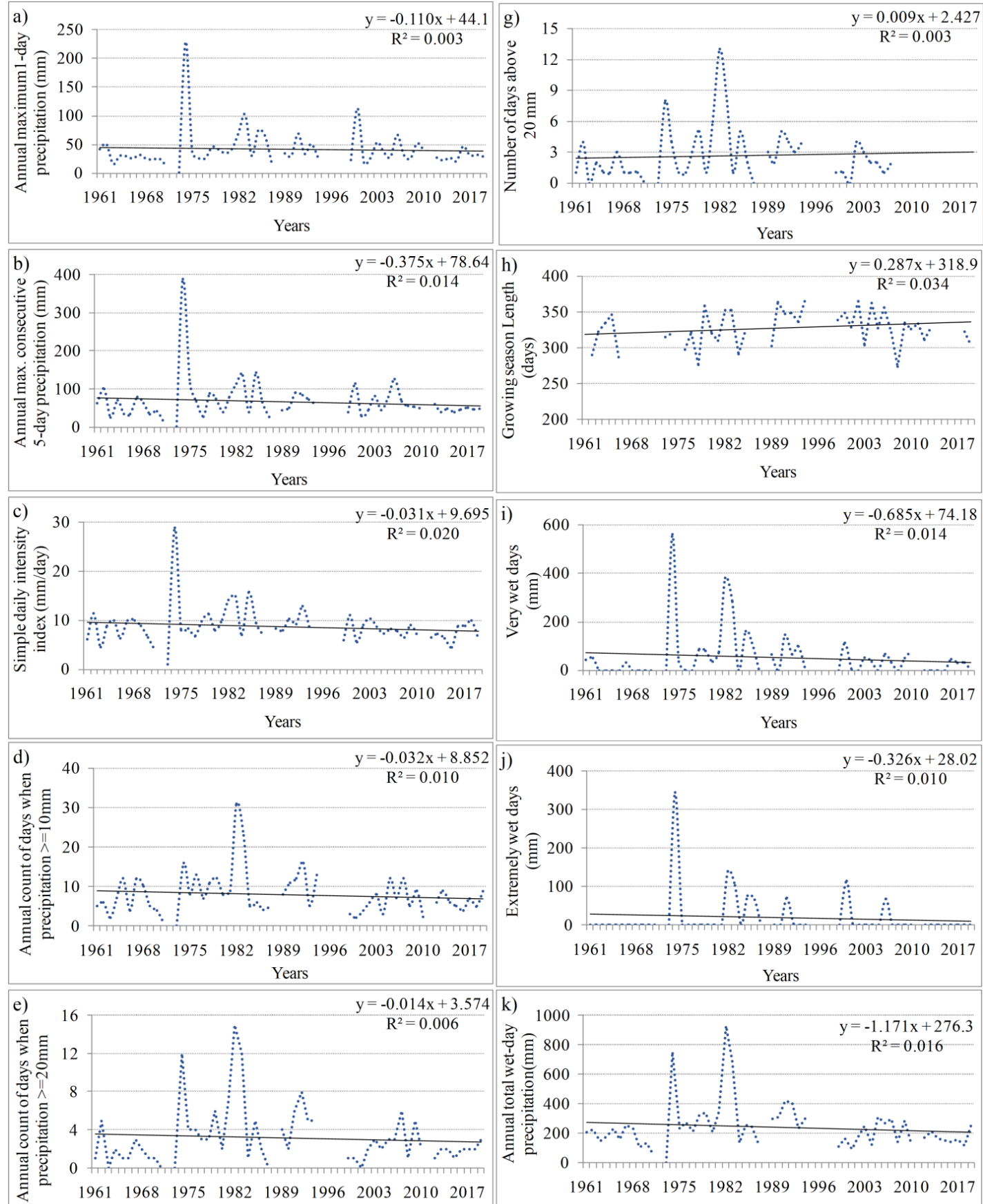

$\begin{array}{lllllllll}1961 & 1968 & 1975 & 1982 & 1989 & 1996 & 2003 & 2010 & 2017\end{array}$

Years Years

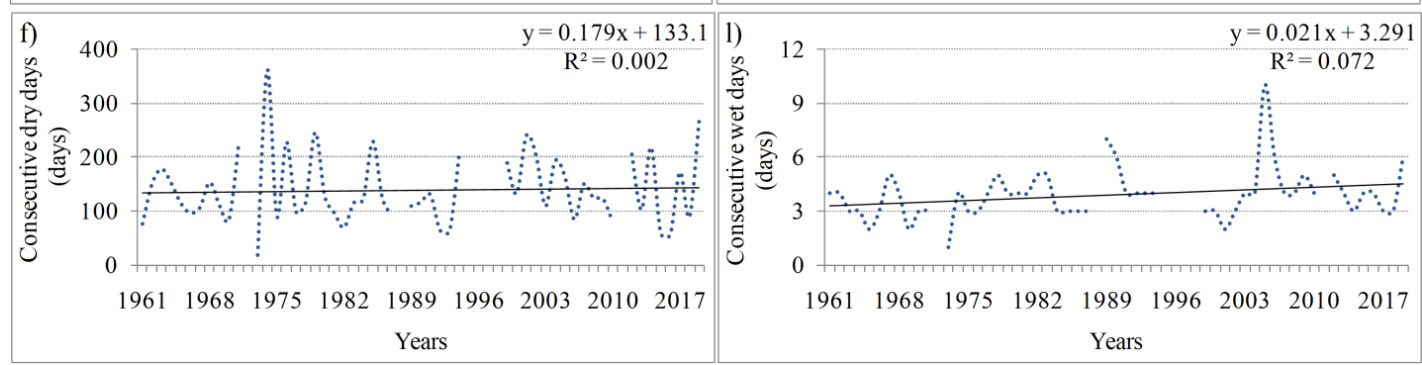

Figure 4 (a-l): Climate extremes indices based on daily rainfall of Quetta Valley.

absolute precipitation for 1-day and 5 consecutive days as well as the precipitation duration for consecutive dry and wet days are calculated as shown in Figure 4. These two indices show a positive increasing trend and 
the highest values of consecutive rainfall were experienced in 1974. These results show a positive increase in consecutive dry and wet days. The highest consecutive dry days are experienced in 1974, whereas the highest wet days were observed in 2005.
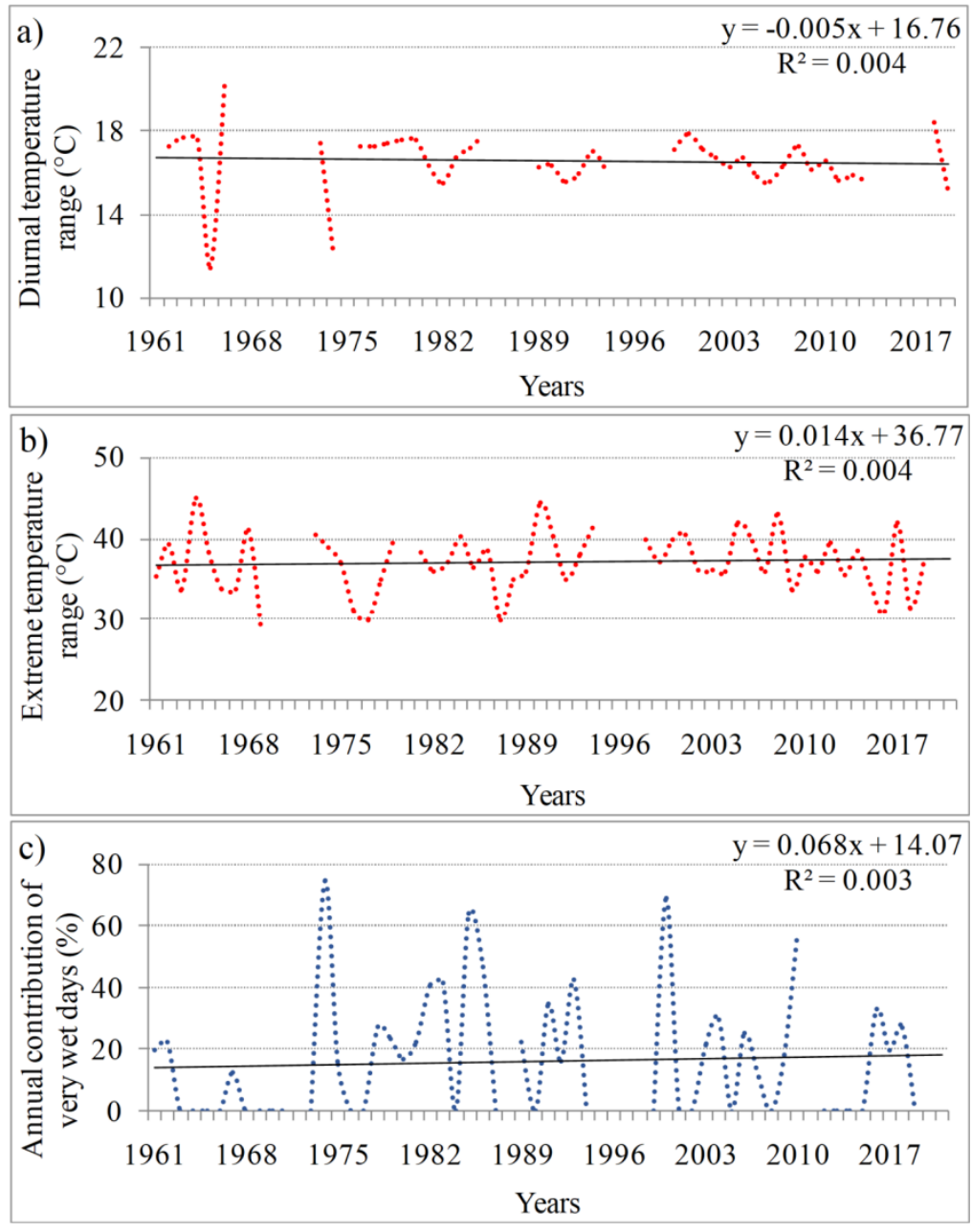

Figure 5: Climate extremes indices based on the daily temperature and rainfall of Quetta Valley.

The growing season length and warm spell duration are increasing sharply, whereas the cold spell shows decreasing trends. These results indicate that the temperature rise has significantly impacted the growing seasonal length as well as the warm and cold spell duration. The total precipitation to daily rainfall intensity and an annual contribution of very wet day precipitation was also calculated. These results show a positive increasing trend for all three indices. The highest annual rainfall was $928.9 \mathrm{~mm}$ during 1982 while the maximum intensity of precipitation was observed during 1974 over Quetta. These results indicate the precipitation-based climate extremes, especially consecutive wet days, are slightly increasing as compared to the rest of the indices. The indices represent an ultimate slight increase in total precipitation over Quetta valley. The time series graphs show a sharp increase in R95PT has been observed. The annual contribution of very 
wet days was maximum (74.5\%) during 1974. The same results have been identified over Pakistan by Ahmed et al., 2015.

The Diurnal temperature range (DTR), extreme temperature range and an annual contribution of very wet days are shown in Figure 5. The entire three variables show a positive increasing trend, which indicates warming over the Quetta valley. These results also determine the frequency of climate extreme indices, which may also change due to change in the minimum and maximum temperature. Urban growth, deforestation, and variations in local land use can all affect the DTR; in particular, urbanized areas often show a narrower DTR than nearby rural areas. Moreover, the extreme temperature range (ETR) of both temperatures (max, min) would also increase. The ETR lies between $30^{\circ} \mathrm{C}$ to $45^{\circ} \mathrm{C}$ with a maximum $\left(20.5^{\circ} \mathrm{C}\right.$ and $\left.45^{\circ} \mathrm{C}\right)$ during 1964. The analysis shows that the extreme temperature range is increasing along with an annual contribution of very wet days.

The time series for the indices of frost days (FD0), mean monthly minimum temperature (TMINmean), tropical nights (TR20), the monthly maximum value of daily minimum temp (TNx), the monthly minimum value of daily minimum temp (TNn), cool nights (TN10P), warm nights (TN90P), and cold spell duration indicator (CSDI) were prepared to analyze. The time-series graphs of said indices are represented (Figure 2 and Figure 3). The prominent increased trends of the TMINmean, TR20, TNx, TNn, and TN90P were observed. These trends represent an increase in the minimum temperature, increase in tropical and warm nights. You et al., 2008 reported a more rapid change in temperature at some high mountains in the Tibetan Plateau than that at low elevations. Due to the increase of said indices, the associated observed parameters considerably decreased for frost days, cool nights and cold spell durations. An increase in the minimum temperature along with its associated indices favours the heatwave increase.

The icy and frost days are decreasing due to the increase in the minimum temperature, which reduces the cold night days and their spell duration. Although, Quetta valley lies in western barren mountains covered with snow during the winter, this overall annual decrease would significantly impact the livelihood of the people living in that area. The warm spell duration has increased, whereas the cold spell duration has decreased. Both figures indicate that the majority of changes in maximum and minimum temperature were experienced during the 1980s. The Sharp increase in the frequency of tropical nights has been observed. The maximum variation in all the indices has been observed after 1990. 
The frequency distribution analysis for the precipitation indices over Quetta valley during the two different periods from 1961-1990 and 1991-2019 was conducted. The maximum increase of $32.50 \%$ in consecutive wet days (CWD) has been observed over Quetta Valley at the 95\% significance level. It has been identified that most of the precipitation indices except R95PT and CDD have decreased in the second half from 1991-2019 as compared to 1961-1990. But, it is not statistically significant, Table 7. The results of these rainfall indices indicate that the reduction of total rainfall along with the cold spell rainfall associated with winter rainfall has decreased over the Quetta valley. Although, the consecutive wet days have increased significantly, it has not enhanced the total rainfall over the valley. The changes in annual rainfall from very wet days (R95PT) contribute significant social impacts (Alexander et al., 2006).

Table 7: Frequency distribution analyses for 12 precipitation indices for two periods; $1961-1990$ and 19912019 of Quetta valley.

\begin{tabular}{|c|c|c|c|c|c|}
\hline \multirow[b]{2}{*}{ Category } & \multirow[b]{2}{*}{ Index name } & \multicolumn{2}{|c|}{ Mean } & \multirow{2}{*}{$\begin{array}{c}\text { Change } \\
\text { between two } \\
\text { means }\end{array}$} & \multirow[b]{2}{*}{ P Value } \\
\hline & & (1961-1990) & (1991-2019) & & \\
\hline \multirow{3}{*}{ Percentile } & R95p & 76.42 & 52.04 & -31.90 & 0.2 \\
\hline & R99p & 26.36 & 21.44 & -18.66 & 0.37 \\
\hline & R10 & 8.84 & 7.83 & -11.39 & 0.26 \\
\hline \multirow[t]{2}{*}{ Threshold } & R20 & 3.72 & 3.39 & -8.90 & 0.31 \\
\hline & Rnn & 2.92 & 2.44 & -16.29 & 0.22 \\
\hline \multirow{2}{*}{ Absolute } & RX1day & 45.39 & 41.2 & -9.24 & 0.31 \\
\hline & RX5day & 78.15 & 66.13 & -15.38 & 0.21 \\
\hline \multirow{3}{*}{ Duration } & CDD & 139.12 & 141.5 & 1.71 & 0.49 \\
\hline & CWD & 3.48 & 4.61 & 32.50 & $0.01 *$ \\
\hline & PRCPTOT & 274.48 & 253.96 & -7.48 & 0.3 \\
\hline \multirow[t]{2}{*}{ Other } & SDII & 9.61 & 8.82 & -8.24 & 0.25 \\
\hline & R95PT & 16.98 & 20.26 & 19.36 & 0.36 \\
\hline
\end{tabular}

*Bold p-value for shift in mean represent significance at $95 \%$ level.

Quetta is the capital city of the Balochistan province and considered one of the atmospherically polluted cities region-wide. Snowfall was a common feature in January till the late eighties, but thereafter, the snowfall has become rare in winters; especially owing to the significant changes in temperature-related indices of the Quetta city. Significant increase in temperature-related indices in Balochistan, with no change in rainfall, may curtail the net irrigation water supply of this already water-scarce region of the country. Temperature indices of desert air over Balochistan have shown a wide diurnal temperature difference. Strong radiative cooling may lead to rapid heat loss after sunset. This may rapidly cool the immediate atmosphere, resulting in 
a surface-based inversion that may have a strong increasing impact on inversion downburst dust storm frequencies over the region. The inversion downburst dust storms have the potential to decrease air visibility to as low as $1 \mathrm{~km}$ and sometimes even lesser.

The variability in meteorological parameters, i.e., increase in temperature and decrease in precipitation will enhance the water loss in the form of evapotranspiration that would ultimately impact the crop water demands in the region. Moreover, the precipitation deficiency will increase the drought frequency and severity that would impact the groundwater recharge and put pressure on the water resources of the region. Increased temperature in urban areas causes a change in the energy balance of Quetta city, often leading to higher temperatures than surrounding rural areas under the phenomenon of the urban heat island effect.

During the quality control, the missing data of both precipitation and temperature have remained a challenge. More importantly, there was only one meteorological station in the Quetta valley which has long term data (1961-2019). So, the number of stations could improve the result and give more confidence to the findings.

\section{Conclusions}

The climate extreme provides a better understanding of observed data changes in temperature and precipitation-based indices for Quetta valley at the $95 \%$ confidence level. The significant increasing trends in temperature based indices show warming over the Quetta valley for the period 1961-2019However, no significant change was observed in precipitation-based indices except for consecutive wet days and an annual contribution of a very wet day, which has significantly increased at the $95 \%$ confidence level. Most importantly, the significant increase in temperature and precipitation based extreme indices shows a clear indication that the frequency of climate extremes has increased over the Quetta valley and more intense rainfall along with a warming trend may be observed in future due to convective rainfall. In light of the above findings, it is concluded that the Quetta valley will face both climate extremes, i.e., droughts and floods (in the form of torrential rainfall) in future. The policymakers should develop a contingency plan keeping in view the current climate extremes (droughts, floods) results to avoid the future calamity over the Quetta valley.

\section{Conflict of interest statement}

The authors have shown no conflict of interest for this publication. 


\section{Author contribution statements}

Imran Hameed Durrani: Conceptualization, Formal analysis, Investigation, review \& editing Shahzada Adnan: Conceptualization, Formal analysis, Investigation, Writing - original draft, Writing - review \& editing. Syed Mobasher Aftab: Supervision, Conceptualization, review and editing.

\section{Acknowledgements}

The authors are grateful to Pakistan Meteorological Department for providing valuable long-term climatological data. The authors are thankful for the anonymous reviewer comments and suggestions that helped to improve the manuscript.

\section{References}

Abbas, F., 2013. Analysis of a historical (1981-2010) temperature record of the Punjab province of Pakistan. Earth Interactions, 17(15), 1-23. DOI: https://doi:10.1175/2013EI000528.1

Abrol, Y. P., \& Ingram, K. T., 1996. Effects of higher day and night temperatures on growth and yields of some crop plants. Global climate change and agricultural production. Direct and indirect effects of changing hydrological, pedological and plant physiological processes. Wiley, Chichester, 124-140. http://www.fao.org/3/w5183e/w5183e08.htm

Adnan, S., \& Ullah, K., 2020. Development of drought hazard index for vulnerability assessment in Pakistan. Natural Hazards, 103(3), 2989-3010. DOI: https://doi.org/10.1007/s11069-020-04116-3

Adnan, S., Ullah, K., \& Gao, S., 2015. Characterization of drought and its assessment over Sindh, Pakistan during 1951-2010. Journal of Meteorological Research,29(5), 837-857. DOI: https://doi.org/10.1007/s13351-015-4113-z

Adnan, S., Ullah, K., Gao, S., Khosa, A. H., \& Wang, Z., 2017. Shifting of agro-climatic zones, their drought vulnerability, and precipitation and temperature trends in Pakistan. International Journal of Climatology, 37, 529-543. DOI: https://doi.org/10.1002/joc.5019

Adnan, S., Ullah, K., \& Shouting, G., 2016. Investigations into precipitation and drought climatologies in South Central Asia with special focus on Pakistan over the period 1951-2010. Journal of Climate, 29(16), 6019-6035. DOI: https://doi.org/10.1175/JCLI-D-15-0735.1 
Adnan, S., Ullah, K., Shuanglin, L., Gao, S., Khan, A. H., \& Mahmood, R., 2018. Comparison of various drought indices to monitor drought status in Pakistan. Climate Dynamics, 51(5), 1885-1899. DOI: https://doi.org/10.1007/s00382-017-3987-0

Afzaal, M., Haroon, M. A., \& Zaman, Q., 2009. Interdecadal oscillations and the warming trend in the areaweighted annual mean temperature of Pakistan. Pakistan Journal of Meteorology, 6(11), 13-19. http://www.pmd.gov.pk/mnd/rndweb/rnd_new/journal.php\#11

Alexander, L. V., Zhang, X., Peterson, T. C., Caesar, J., Gleason, B., Klein Tank, A. M. G., ... \& VazquezAguirre, J. L., 2006. Global observed changes in daily climate extremes of temperature and precipitation. Journal of Geophysical Research: Atmospheres, 111(D5). DOI: https://doi.org/10.1029/2005JD006290

Ashraf, M., \& ul Hasan, F., 2020. Groundwater Management in Balochistan, Pakistan (No. 33241). The World Bank. https://documents1.worldbank.org/curated/en/410961579803784924/pdf/GroundwaterManagement-in-Balochistan-Pakistan-A-Case-Study-of-Karez-Rehabilitation.pdf

Boccolari, M., \& Malmusi, S., 2013. Changes in temperature and precipitation extremes observed in Modena, Italy. Atmospheric Research, 122, 16-31. DOI: https://doi.org/10.1016/j.atmosres.2012.10.022

Ahmad, B., Haider, S., \& Bukhari, S. A. A., 2015. Regional precipitation response to regional warming in past and future climate. Pakistan Journal of Meteorology, 11(22). DOI: http://www.pmd.gov.pk/mnd/rndweb/rnd_new/journal.php\#22

Ahmad, B., \& Rasul, G., 2018. Statistically downscaled projections of CORDEX South Asia using quantile mapping approach over Pakistan region. International Journal of Global Warming, 16(4), 435-460. DOI: https://doi.org/10.1504/IJGW.2018.095996

Choi, G., Collins, D., Ren, G., Trewin, B., Baldi, M., Fukuda, Y., ... \& Zhou, Y., 2009. Changes in means and extreme events of temperature and precipitation in the Asia-Pacific Network region, 1955 2007. International Journal of Climatology: A Journal of the Royal Meteorological Society, 29(13), 1906-1925. DOI: https://doi.org/10.1002/joc.1979

del Rio, S., Anjum Iqbal, M., Cano-Ortiz, A., Herrero, L., Hassan, A., \& Penas, A., 2013. Recent mean temperature trends in Pakistan and links with teleconnection patterns. International Journal of Climatology, 33(2), 277-290. DOI: https://doi.org/10.1002/joc.3423

Du, J., Fang, J., Xu, W., \& Shi, P., 2013. Analysis of dry/wet conditions using the standardized precipitation index and its potential usefulness for drought/flood monitoring in Hunan Province, China. Stochastic environmental research and risk assessment, 27(2), 377-387. DOI: https://doi.org/10.1007/s00477-0120589-6 
Durrani, I. H., Adnan, S., Ahmad, M., Khair, S. M., \& Kakar, E., 2018. Observed long-term climatic variability and its impacts on the ground water level of Quetta alluvial. Iranian Journal of Science and Technology, Transactions A: Science, 42(2), 589-600. DOI: https://doi.org/10.1007/s40995-017-02358

Fischer, G., Shah, M., N. Tubiello, F., \& Van Velhuizen, H., 2005. Socio-economic and climate change impacts on agriculture: an integrated assessment, 1990-2080. Philosophical Transactions of the Royal Society B: Biological Sciences, 360(1463), 2067-2083. DOI: https://doi.org/10.1098/rstb.2005.1744

Frich, P., Alexander, L. V., Della-Marta, P. M., Gleason, B., Haylock, M., Tank, A. K., \& Peterson, T., 2002. Observed coherent changes in climatic extremes during the second half of the twentieth century. Climate Research, 19(3), 193-212. https://www.int-res.com/abstracts/cr/v19/n3/p193-212/

Gazdar, H., Kaker, S. A., \& Khan, I., 2010. Buffer Zone, Colonial Enclave or Urban Hub? Quetta: between four regions and two wars. http://eprints.lse.ac.uk/28472/

Gocic, M., \& Trajkovic, S., 2014. Analysis of trends in reference evapotranspiration data in a humid $\begin{array}{llll}\text { climate. Hydrological } & \text { Sciences } & \text { Journal, 59(1), } & \text { 165-180. }\end{array}$ https://doi.org/10.1080/02626667.2013.798659

Griffiths, G. M., Chambers, L. E., Haylock, M. R., Manton, M. J., Nicholls, N., Baek, H. J., ... \& Zhai, P., 2005. Change in mean temperature as a predictor of extreme temperature change in the Asia-Pacific region. International Journal of Climatology: A Journal of the Royal Meteorological Society, 25(10), 1301-1330. DOI: https://doi.org/10.1002/joc.1194

Griggs, D. J., \& Noguer, M., 2002. Climate change 2001: the scientific basis. Contribution of working group I to the third assessment report of the intergovernmental panel on climate change. Weather, 57(8), 267269. DOI: https://doi.org/10.1256/004316502320517344

Haider, S., \& Adnan, S., 2014. Classification and assessment of aridity over Pakistan provinces (19602009). International Journal of Environment, 3(4), 24-35. DOI: https://doi.org/10.3126/ije.v3i4.11728

Hanif, M., Khan, A. H., \& Adnan, S., 2013. Latitudinal precipitation characteristics and trends in Pakistan. Journal of Hydrology, 492, 266-272. DOI: https://doi.org/10.1016/j.jhydrol.2013.03.040

Huber, D. G., \& Gulledge, J., 2011. Extreme weather and climate change: Understanding the link, managing the risk. Arlington: Pew Center on Global Climate Change.https://www.researchgate.net/profile/JayGulledge/publication/250306443_Extreme_Weather_ and_Climate_Change_Understanding_the_Link_and_Managing_the_Risk/links/0046351e9c8578bd5 4000000/Extreme-Weather-and-Climate-Change-Understanding-the-Link-and-Managing-the-

Risk.pdf 
Hunt, K. M., Turner, A. G., \& Shaffrey, L. C., 2020. The impacts of climate change on the winter water cycle of the western Himalaya. Climate Dynamics, 55(7), 2287-2307. DOI: https://doi.org/10.1007/s00382020-05383-3

Hussain, M. S., \& Lee, S., 2014. Long-term variability and changes of the precipitation regime in Pakistan. Asia-Pacific Journal of Atmospheric Sciences, 50(3), 271-282. DOI: https://doi.org/10.1007/s13143-014-0015-8

IPCC (Intergovernmental Panel on Climate Change)., 2007. Climate Change 2007: The Physical Science Basis. Contribution of Working Group I to the Fourth Assessment Report of the Intergovernmental Panel on Climate Change, Solomon, S., Qin, D., Manning, M., Chen, Z.,Marquis, M., Averyt, K.B., Tignor, M., Miller, H.L., (eds.). Cambridge University Press: Cambridge, UK; New York, NY, USA. https://books.google.com.pk/books?hl=en\&lr=\&id=8m8nXB8GB4C\&oi=fnd\&pg=PA339\&dq=\%E 2\%80\%A2\%09IPCC+(Intergovernmental+Panel+on+Climate+Change).+(2007).+Climate+Change+ 2007:+The+Physical+Science+Basis.+Contribution+of+Working+Group+I+to+the+Fourth+Assessm ent+Report+of+the+Intergovernmental+Panel+on+Climate+Change,+Solomon, +S.,+Qin,+D.,+Mann ing,+\&ots=hBgoz5qfOY\&sig=sWUd-ubJVvTyrJNQNQou81SUWcs\&redir_esc=y

Ikram, F., Afzaal,M., Bukhari, S.A.A., Ahmed, B., 2016. Past and Future Trends in Frequency of Heavy Rainfall Events over Pakistan. Pak. J. Meteor., 12(24), 57-78. DOI: http://www.pmd.gov.pk/mnd/rndweb/rnd_new/journal.php\#24

Kazmi, D.H., Li, J., Rasul, G.,Tong, J., Ali, G., Cheema,S.B., Liu, L., Gemmer, M., Fischer, T., 2015. Statistical downscaling and future scenario generation of temperatures for Pakistan Region. Theoretical and Applied Climatol., 120(1-2),341-350. DOI: https://doi.org/10.1007/s00704-014-1176-1

Kalnay, E., \& Cai, M., 2003. Impact of urbanization and land-use change on climate. Nature, 423(6939), 528531. DOI: https://doi.org/10.1038/nature01675

Li, Q., \& Xue, Y., 2010. Simulated impacts of land cover change on summer climate in the Tibetan Plateau. Environmental Research Letters, 5(1), 015102. https://iopscience.iop.org/article/10.1088/17489326/5/1/015102/meta

Mann, H. B., 1945. Nonparametric tests against trend. Econometrica: Journal of the econometric society, 245259. DOI: https://doi.org/10.2307/1907187

Manton, M. J., Della-Marta, P. M., Haylock, M. R., Hennessy, K. J., Nicholls, N., Chambers, L. E., ... \& Yee, D., 2001. Trends in extreme daily rainfall and temperature in Southeast Asia and the South Pacific: 19611998. International Journal of Climatology, 21(3), 269-284. DOI: https://doi.org/10.1002/joc.610

Meehl, G. A., \& Tebaldi, C., 2004. More intense, more frequent, and longer lasting heat waves in the 21st century. Science, 305(5686), 994-997. DOI: https://doi.org/10.1126/science.10 98704 
Parry, M. L., Rosenzweig, C., Iglesias, A., Livermore, M., \& Fischer, G., 2004. Effects of climate change on global food production under SRES emissions and socio-economic scenarios. Global Environmental Change, 14(1), 53-67. DOI: https://doi.org/10.1016/j.gloenvcha.2003.10.008

Rosenzweig, C., \& Parry, M. L., 1994. Potential impact of climate change on world food supply. Nature, 367(6459), 133-138. DOI: https://doi.org/10.1038/367133a0

Roy, S. S., Mahmood, R., Niyogi, D., Lei, M., Foster, S. A., Hubbard, K. G., .. \& Pielke Sr, R., 2007. Impacts of the agricultural Green Revolution-induced land use changes on air temperatures in India. Journal of Geophysical Research: Atmospheres, 112(D21). DOI: https://doi.org/10.1029/2007JD008834

Safeeq, M., Mair, A., \& Fares, A., 2013. Temporal and spatial trends in air temperature on the Island of Oahu, Hawaii. International Journal of Climatology, 33(13), 2816-2835. DOI: https://doi.org/10.1002/joc.3629 Sagintayev, Z., Sultan, M., Khan, S. D., Khan, S. A., Mahmood, K., Yan, E., ... \& Marsala, P., 2012. A remote sensing contribution to hydrologic modelling in arid and inaccessible watersheds, Pishin Lora basin, Pakistan. Hydrological Processes, 26(1), 85-99. DOI: https://doi.org/10.1002/hyp.8114

Sajjad, H., \& Ghaffar, A., 2019. Observed, simulated and projected extreme climate indices over Pakistan in changing climate. Theoretical and Applied Climatology, 137(1), 255-281. DOI: https://doi.org/10.1007/s00704-018-2573-7

Sen, P.K., 1968. Estimates of the regression coefficient based on Kendall's tau. Journal of the American Statistical Association, 63, 1379-1389. DOI: https://doi.org/10.1080/01621459.1968.10480934

Sen, Roy. S., Balling, Jr. R.C., 2004. Trends in extreme daily precipitation indices in India. International Journal of Climatology, 24,457-66. DOI: https://doi.org/10.1002/joc.995

Srinivas, K., \& Kumar, P. D., 2006. Atmospheric forcing on the seasonal variability of sea level at Cochin, southwest coast of India. Continental shelf research,26(10), 1113-1133. DOI: https://doi.org/10.1016/j.csr.2006.03.010

Stocker, T.F., Qin, D., Plattner, G.K.,Tignor, M,,Allen, S.K., Boschung, J., Midgley, P.M., 2013. Climate change 2013: The physical science basis. Intergovernmental Panel on Climate Change, Working Group I contribution to the IPCC 5th Assessment Report. http://www.ipcc.ch/pdf/assessmentreport/ar5/wg1/WG1AR5_Chapter02_FINAL.pdf.

Tabari, H., Abghani, H., Hosseinzadeh,Talaee. P., 2012. Temporal trends and spatial characteristics of drought and rainfall in arid and semiarid regions of Iran. Hydrol Process, 22, 3351-3361. DOI: https://doi.org/10.1002/hyp.8460

Tabari, H., Somee, B.S., Zadeh, M.R., 2011. Testing for long-term trends in climatic variables in Iran. Atmos Res., 100,132-140. DOI: https://doi.org/10.1016/j.atmosres.2011.01.005 
Tebaldi, C., Hayhoe, K., Arblaster, J.M., Meehl, G.A., 2006. Going to the extremes. Climatic Change., 79,185-211. DOI: https://doi.org/10.1007/s10584-006-9051-4

Treydte, K.S., Schleser, G.H., Helle, G., Frank, D.C., Winiger, M., Haug, G.H., Esper, J., 2006. The twentieth century was the wettest period in northern Pakistan over the past millennium. Nature, 440(7088), 11791182. DOI: https://doi.org/10.1038/nature04743

Xuebin, Z. and Yang, F., 2004. RClimDex (1.0), User Manual. Climate Research Branch, Environment Canada, Downsview, Ontario, Canada. https://ensembles-eu.metoffice.gov.uk/C3SDR/pages/workshop_tools/RClimDexUserManual.pdf

Yan, Z., Jones, P.D., Davies, T.D., Moberg, A., Bergström, H., Camuffo, D., Cocheo, C., Maugeri, M., Demarée, G.R., Verhoeve, T., Thoen, E., 2002. Trends of extreme temperatures in Europe and China based on daily observations. In Improved understanding of past climatic variability from early daily European instrumental sources 2002 (pp. 355-392). Springer, Dordrecht. https://link.springer.com/chapter/10.1007/978-94-010-0371-1_13

You, Q., Kang, S., Pepin, N., \& Yan, Y., 2008. Relationship between trends in temperature extremes and elevation in the eastern and central Tibetan Plateau, 1961-2005. Geophysical Research Letters, 35(4). DOI: https://doi.org/10.1029/2007GL032669

Zhang, A., Zheng, C., Wang, S., Yao, Y., 2015. Analysis of streamflow variations in the Heihe River Basin, northwest China: trends, abrupt changes, driving factors and ecological influences. J Hydrol. Reg Study, 3,106-124. DOI: https://doi.org/10.1016/j.ejrh.2014.10.005

Zhang, Q., Xu, C.Y., Tao, H., Jiang, T., Chen, Y.D., 2010. Climate changes and their impacts on water resources in the arid regions: a case study of the Tarim River basin, China. Stochastic Environmental Research and Risk Assessment 24,349-358. DOI: https://doi.org/10.1007/s00477-009-0324-0

Zhang, X., Alexander, L., Hegerl, G. C., Jones, P., Tank, A. K., Peterson, T. C., ... \& Zwiers, F. W., 2011. Indices for monitoring changes in extremes based on daily temperature and precipitation data. Wiley Interdisciplinary Reviews: Climate Change, 2(6), 851-870. DOI: https://doi.org/10.1002/wcc.147

Zhao, Y., 2015. Trends of Air Temperature, Precipitation and Potential Evapotranspiration in Southeastern United States and East-central China (Ph.D. dissertation, The Ohio State University). 193pp. https://www.semanticscholar.org/paper/Trends-of-Air-Temperature\%2C-Precipitation-and-in-andZhao/d725987f71d15d635c13eff2de583eb90ea7ff0a 


\section{Appendix}

Table A1 Types of water-points in Quetta Sub-basin

\begin{tabular}{lccccc}
\hline \multicolumn{1}{c}{ Type/Use } & Irrigation & Domestic & Water Supply & Dried & Total \\
\hline Kareze & 3 & 0 & 0 & 4 & 7 \\
Springs & 10 & 2 & 1 & 23 & 36 \\
Dug Wells & 0 & 1048 & 0 & 81 & 1129 \\
Tube-wells & 1310 & 76 & 672 & 386 & 2444 \\
Total & 1323 & 1126 & 673 & 494 & 3616 \\
\hline
\end{tabular}

Table A2 Water Balance for Quetta Water Supply,

\begin{tabular}{|c|c|c|c|}
\hline $\begin{array}{l}\text { Period } \\
\text { (Year) }\end{array}$ & $\begin{array}{c}\text { Water Demand } \\
\left(\mathbf{m}^{3} / \text { day }\right)\end{array}$ & $\begin{array}{c}\text { Sustainable } \\
\text { Water Available } \\
\left(\mathbf{m}^{3} / \text { day }\right)\end{array}$ & $\begin{array}{l}\text { Supplementary water required } \\
\text { from different sources } \\
\text { (m/day) }\end{array}$ \\
\hline 2000 & 103050.26 & 59654.30 & 43395.96 \\
\hline 2009 & 139605.98 & 59654.30 & 79951.68 \\
\hline 2010 & 143989.49 & 59654.30 & 84335.18 \\
\hline 2020 & 218634.02 & 59654.30 & 155194.31 \\
\hline 2030 & 300145.30 & 59654.30 & 240490.99 \\
\hline 2040 & 375308.43 & 59654.30 & 316676.19 \\
\hline 2042 & 393959.16 & 59654.30 & 334304.85 \\
\hline
\end{tabular}

Table A3 Explanation of core extreme temperature and precipitation indices.

\begin{tabular}{|c|c|c|c|c|}
\hline Category & Index name & ID & Definition & Units \\
\hline \multicolumn{5}{|c|}{ Temperature } \\
\hline \multirow{5}{*}{ Percentile } & Cool nights & TN10p & Percentage of days when $\mathrm{TN}<10$ th percentile & Days \\
\hline & Cool days & TX10p & Percentage of days when $\mathrm{TX}<10$ th percentile & Days \\
\hline & Warm nights & TN90p & Percentage of days when $\mathrm{TN}>90$ th percentile & Days \\
\hline & Warm days & TX90p & Percentage of days when $\mathrm{TX}>90$ th percentile & Days \\
\hline & Frost days & FD0 & Annual count when $\mathrm{TN}$ (daily minimum) $<0^{\circ} \mathrm{C}$ & Days \\
\hline \multirow{3}{*}{ Threshold } & Summer days & SU25 & Annual count when $\mathrm{TX}$ (daily maximum) $>25^{\circ} \mathrm{C}$ & Days \\
\hline & Ice days & ID0 & Annual count when $\mathrm{TX}$ (daily maximum) $<0^{\circ} \mathrm{C}$ & Days \\
\hline & Tropical nights & TR20 & Annual count when $\mathrm{TN}$ (daily minimum) $>20^{\circ} \mathrm{C}$ & Days \\
\hline \multirow{5}{*}{ Absolute } & Warmest day & TXx & Annual maximum value of daily maximum temp & ${ }^{\circ} \mathrm{C}$ \\
\hline & Warmest night & $\mathrm{TNx}$ & Annual maximum value of daily minimum temp & ${ }^{\circ} \mathrm{C}$ \\
\hline & Coldest day & TXn & Annual minimum value of daily maximum temp & ${ }^{\circ} \mathrm{C}$ \\
\hline & Coldest night & TNn & Annual minimum value of daily minimum temp & ${ }^{\circ} \mathrm{C}$ \\
\hline & Diurnal temp range & DTR & Annual mean difference between TX and TN & ${ }^{\circ} \mathrm{C}$ \\
\hline \multirow[t]{2}{*}{ Duration } & Growing season length & GSL & $\begin{array}{l}\text { Annual (1st Jan to } 31 \text { st Dec in Northern Hemisphere, 1st } \\
\text { July to 30th June in Southern Hemisphere) count between } \\
\text { first span of at least } 6 \text { days with TG }>5^{\circ} \mathrm{C} \text { and first span } \\
\text { after July } 1 \text { (January 1st in SH) of } 6 \text { days with } \mathrm{TG}<5^{\circ} \mathrm{C}\end{array}$ & Days \\
\hline & $\begin{array}{l}\text { Warm spell duration } \\
\text { indicator }\end{array}$ & WSDI & $\begin{array}{l}\text { Annual count of days with at least } 6 \text { consecutive days } \\
\text { when } T X>90 \text { th percentile }\end{array}$ & Days \\
\hline
\end{tabular}




\begin{tabular}{|c|c|c|c|c|}
\hline \multirow{3}{*}{ Others } & $\begin{array}{l}\text { Cold spell duration } \\
\text { indicator }\end{array}$ & CSDI & $\begin{array}{l}\text { Annual count of days with at least } 6 \text { consecutive days } \\
\text { when } T N<10 \text { th percentile }\end{array}$ & Days \\
\hline & Mean Min. Temp. & TMINmean & Mean of daily minimum temperature & ${ }^{\circ} \mathrm{C}$ \\
\hline & Mean Max. Temp. & TMAXmean & Mean of daily maximum temperature & ${ }^{\circ} \mathrm{C}$ \\
\hline \multicolumn{2}{|c|}{ Extreme temperature range } & ETR & $\mathrm{ETR}=\mathrm{TX}_{\mathrm{X}}-\mathrm{TN}_{\mathrm{n}}$ & ${ }^{\circ} \mathrm{C}$ \\
\hline \multicolumn{5}{|c|}{ Precipitation } \\
\hline \multirow{2}{*}{ Percentile } & Very wet days & R95p & Annual total PRCP when $\mathrm{RR}>95^{\text {th }}$ percentile & $\mathrm{mm}$ \\
\hline & Extremely wet days & R99p & Annual total $\mathrm{PRCP}$ when $\mathrm{RR}>99^{\mathrm{th}}$ percentile & $\mathrm{mm}$ \\
\hline \multirow{3}{*}{ Threshold } & $\begin{array}{l}\text { Heavy precipitation } \\
\text { days }\end{array}$ & R10 & Annual count of days when $P R C P>=10 \mathrm{~mm}$ & Days \\
\hline & $\begin{array}{l}\text { Very heavy precipitation } \\
\text { days }\end{array}$ & $\mathrm{R} 20$ & Annual count of days when $P R C P>=20 \mathrm{~mm}$ & Days \\
\hline & Days above nn mm & Rnn & Annual count of days when $P R C P>=23 \mathrm{~mm}$ & Days \\
\hline \multirow{2}{*}{ Absolute } & Max 1-day precipitation & RX1day & Annual maximum 1-day precipitation & $\mathrm{mm}$ \\
\hline & Max 5-day precipitation & RX5day & Annual maximum consecutive 5-day precipitation & $\mathrm{mm}$ \\
\hline \multirow{2}{*}{ Duration } & Consecutive dry days & $\mathrm{CDD}$ & Maximum number of consecutive days with $\mathrm{RR}<1 \mathrm{~mm}$ & Days \\
\hline & Consecutive wet days & CWD & Max. No. of consecutive days with $R R>=1 \mathrm{~mm}$ & Days \\
\hline \multirow{2}{*}{ Other } & $\begin{array}{l}\text { Annual total wet-day } \\
\text { precipitation }\end{array}$ & PRCPTOT & Annual total PRCP in wet days (RR>=1mm) & $\mathrm{mm}$ \\
\hline & $\begin{array}{l}\text { Simple daily intensity } \\
\text { index }\end{array}$ & SDII & $\begin{array}{l}\text { Annual total precipitation divided by the number of wet days } \\
\text { (defined as } \mathrm{PRCP}>=1.0 \mathrm{~mm} \text { ) in a year }\end{array}$ & $\begin{array}{l}\mathrm{mm} / \mathrm{da} \\
\mathrm{y}\end{array}$ \\
\hline \multicolumn{2}{|c|}{ Annual contribution of very wet days } & R95PT & $\mathrm{R} 95 \mathrm{PT}=\left(\frac{\mathrm{R} 95 \mathrm{P}}{\mathrm{PRCPTOT}}\right) \times 100$ & $\%$ \\
\hline
\end{tabular}

